\title{
The Catalytic Function of Nonheme Iron (III) Complex for Hydrocarbon Oxidation
}

\author{
Giorgos Bilis and Maria Louloudi \\ Department of Chemistry, University of Ioannina, 45110 Ioannina, Greece \\ Correspondence should be addressed to Maria Louloudi, mlouloud@uoi.gr \\ Received 13 March 2010; Accepted 10 May 2010 \\ Academic Editor: Spyros Perlepes
}

Copyright (๑) 2010 G. Bilis and M. Louloudi. This is an open access article distributed under the Creative Commons Attribution License, which permits unrestricted use, distribution, and reproduction in any medium, provided the original work is properly cited.

A detailed catalytic study of $\mathrm{LFe}{ }^{\mathrm{III}} \mathrm{Cl}$ (where $\mathrm{L}=3$-\{2-[2-(3-hydroxy-1,3-diphenyl-allylideneamino)-ethylamino]-ethylimino $\}$ 1,3-diphenyl-propen-1-ol) for hydrocarbon oxidation was carried out, focusing on the role of solvent, atmospheric dioxygen, and oxidant on catalytic efficiency. The data showed that $\mathrm{LFe}{ }^{\mathrm{III}} \mathrm{Cl}$ catalyst was efficient in homogeneous hydrocarbon oxidations providing significant yields. Moreover, tert-BuOOH provided comparable oxidation yields with $\mathrm{H}_{2} \mathrm{O}_{2}$, slightly favoring the formation of alcohols and ketones versus epoxides. Dioxygen intervened in the catalytic reaction, influencing the nature of oxidation products. The polarity of solvent strongly influenced the reaction rates and the nature of oxidation products. A mechanistic model is postulated assuming that $\mathrm{LFe}^{\mathrm{III}} \mathrm{Cl}$ functions via the formation of iron-hydroperoxo-species, followed by a radical-based mechanistic path.

\section{Introduction}

Hydrocarbon oxidation, under mild and environmental friendly conditions, is an important research field, since industrial processes, especially in pharmaceutical industry, are based on the efficiency of direct and selective transformation of hydrocarbons in oxygen-containing products such as aldehydes, ketones alcohols, diols, and epoxides $[1,2]$. However, selective oxidation of alkanes, under mild conditions, is a difficult task due to their chemical inertness. Nevertheless, in nature many iron enzymes activate dioxygen and catalyze the stereospesific oxidation of $\mathrm{C}=\mathrm{C}$ or $\mathrm{C}-$ $\mathrm{H}$ bonds [3, 4]. Heme iron-proteins such as hemoglobin, myoglobin and cytochromes oxygenase [5] and nonheme enzymes such as methane monooxygenase $[6,7]$ and Rieske dioxygenases $[8,9]$ are able to oxidize hydrocarbons [10] via biochemical oxygen transport and electron-transfer reactions.

The objective to construct convenient artificial systems for efficient hydrocarbon oxidation using biomimetic iron complexes [11, 12] as catalysts [13-15] by activating green oxidants is particularly interesting. Bioinspired catalytic systems commonly use mild oxidants such as dioxygen, hydrogen peroxide, or tert-butyl hydrogen peroxide (TBHP) [16-
20]. In this context, stereoselective hydroxylation, epoxidation, and cis-dihydroxylation by synthetic iron-biomimetic catalysts have been reported [21-29]. Iron-peroxo species are invoked to be part of the mechanism of several bioinspired oxidation catalysts $[30,31]$. More particularly, ironcomplexes react with $\mathrm{H}_{2} \mathrm{O}_{2}$ or alkyl hydroperoxides forming low-spin $\mathrm{Fe}^{\mathrm{III}} \mathrm{OOH}[32,33]$ or $\mathrm{Fe}^{\mathrm{III}} \mathrm{OOR}[34,35]$ which are the key-species in oxidation reactions [16].

Recently, we have reported the synthesis and characterization of the ligand 3-\{2-[2-(3-hydroxy-1,3-diphenyl-allylideneamino)-ethylamino]-ethylimino 3 -1,3-diphenyl-propen- 1-ol and its immobilization on silica surface via formation of covalent bridging between the ligand secondary amine and the silica $\mathrm{OH}$-groups $[36,37]$. Herein for brevity this ligand will be named $\mathbf{L}$. The corresponding $\mathrm{Mn}$ (II) $[36,37]$ and $\mathrm{Fe}$ (III) [38] catalysts were shown to have remarkable catalytic activity in hydrocarbons oxidation using $\mathrm{H}_{2} \mathrm{O}_{2}$ as oxidant.

In the present contribution, we report a detailed catalytic study of $\mathrm{LFe}^{\mathrm{III}} \mathrm{Cl}$ focusing mainly on the influence of (a) atmospheric dioxygen, (b) solvent system, and (c) oxidant on its catalytic efficiency. The obtained information is compared with previous data of the $\mathrm{LFe}^{\mathrm{III}} \mathrm{Cl}$ catalyst, and mechanistic aspects are also discussed. 


\section{Experimental}

2.1. General. All substrates were purchased from Aldrich, in their highest commercial purity, stored at $5^{\circ} \mathrm{C}$ and purified by passage through a column of basic alumina prior to use. Hydrogen peroxide was $30 \%$ aqueous solution and tert$\mathrm{BuOOH}$ was $5 \mathrm{M}$ solution in decane.

Infrared spectra were recorded on a Spectrum GX Perkin-Elmer FT-IR System. UV-Vis spectra were recorded using a UV/VIS/NIR JASCO Spectrophotometer. The iron amount was determined by Flame Atomic Absorption spectroscopy on a Perkin-Elmer AAS-700 spectrometer. Mössbauer spectra were recorded with a constant acceleration spectrometer using a ${ }^{57} \mathrm{Co}(\mathrm{Rh})$ source at room temperature and a variable-temperature. X-band Electron Paramagnetic Resonance (EPR) spectra were recorded using a Brucker ER200D spectrometer at liquid $\mathrm{N}_{2}$ temperatures, equipped with an Agilent 5310A frequency counter. The spectrometer was running under a home-made software based on LabView described earlier [39]. Mass spectra were measured on a Agilent 1100 Series LC-MSD-Trap-SL spectrometer and solution. Thermogravimetric analyses were carried out using Shimadzu DTG-60 analyser. GC analysis was performed using an 8000 Fisons chromatograph with a flame ionization detector and a Shimadzu GC-17A gas chromatograph coupled with a GCMS-QP5000 mass spectrometer.

\subsection{Catalysts Preparation and Characterization}

2.2.1. Preparation of $\mathrm{LFe}^{I I I} \mathrm{Cl}$. To a stirred solution of ethanol and acetonitrile $(15 \mathrm{ml})$ containing the ligand $\mathbf{L}=3$-\{2-[2-(3-hydroxy-1,3-diphenyl-allylideneamino)-

ethylamino]-ethylimino $\}$-1,3-diphenyl-propen-1-ol [36, 37] a solution of $\mathrm{FeCl}_{3}$ in a mixture of $\mathrm{EtOH}$ and $\mathrm{CH}_{3} \mathrm{CN}$ was added slowly. The resulting mixture was stirred for $24 \mathrm{~h}$ at room temperature. Partially solvent evaporation resulted in separation of an orange solid product. The obtained $\mathrm{LFe}{ }^{\mathrm{III}} \mathrm{Cl}$ complex was washed with EtOH and $\mathrm{CH}_{3} \mathrm{CN}$ and dried under reduced pressure.

2.2.2. Characterization of $\mathrm{LFe} e^{I I I} \mathrm{Cl}$. Iron analysis by Flame Atomic Absorbance Spectroscopy and ESI-MS analysis indicated a molecular peak at $\mathrm{m} / z 605.2$ that is attributed in $[\mathrm{LFeCl}+\mathrm{H}]^{+}$formation. The IR bands at 3297, 1591, and $1523 \mathrm{~cm}^{-1}$ were attributed to the $v(\mathrm{NH}), v(\mathrm{C}=\mathrm{N})$, and $\delta(\mathrm{NH})$ vibrations. In the spectrum of the metal-free ligand $\mathrm{L}$ , the corresponding vibrations were detected at 3350, 1600, and $1535 \mathrm{~cm}^{-1}$; this shift indicates metal coordination to imine- and amine-nitrogen. In the IR spectra of $\mathbf{L}$ and the $\mathrm{LFe}^{\mathrm{III}} \mathrm{Cl}$ the $v(\mathrm{C}-\mathrm{O})$ vibration was appeared at 1398 and $1389 \mathrm{~cm}^{-1}$, respectively, suggesting strong coordination of Fe to the enolic oxygen atoms of the ligand L. Information about the iron center was obtained by Electron Paramagnetic Resonance (EPR) and Mössbauer spectroscopy. At $78 \mathrm{~K}$, the Mössbauer parameters are $\delta=0.50 \mathrm{~mm} / \mathrm{s}$ and $\Delta_{\mathrm{EQ}}=$ $0.54 \mathrm{~mm} / \mathrm{s}$ indicating an octahedral high-spin $\mathrm{Fe}^{\mathrm{III}}(\mathrm{S}=$ $5 / 2$ ) center, with the iron bound to nitrogen and oxygen atom donors [40]. The EPR spectrum of solid $\mathrm{LFe}^{\mathrm{III}} \mathrm{Cl}$ is characerised by two peaks at $\mathrm{g}=4.3$ and 9.2, characteristic of a high-spin $\mathrm{Fe}^{\mathrm{III}}(\mathrm{S}=5 / 2)$ center in a rhombic ligand-field characterized by E/D 0.33 [41]. The UV-Vis spectrum of $\mathrm{LFe}{ }^{\mathrm{III}} \mathrm{Cl}$ in $\mathrm{CH}_{3} \mathrm{CN}$ contains absorption bands at $282(\varepsilon=$ $\left.20800 \mathrm{M}^{-1} \mathrm{~cm}^{-1}\right)$ and $314 \mathrm{~nm}\left(\varepsilon=25580 \mathrm{M}^{-1} \mathrm{~cm}^{-1}\right)$ due to intraligand transitions in the imine- and phenyl-groups [42]. The absorptions at $413 \mathrm{~nm}\left(\varepsilon=7100 \mathrm{M}^{-1} \mathrm{~cm}^{-1}\right)$ and $512 \mathrm{~nm}\left(\varepsilon=2000 \mathrm{M}^{-1} \mathrm{~cm}^{-1}\right)$ are attributed to LMCT [43]. The low-intensity $512 \mathrm{~nm}$ absorption can be attributed to charge transfer from ligand oxygen atoms to metal centre $\left(\mathrm{p}_{\pi} \rightarrow \mathrm{Fe}^{\mathrm{III}} \mathrm{d}_{\pi}\right)$. Usually, a $\left(\mathrm{p}_{\pi} \rightarrow \mathrm{Fe}^{\mathrm{III}} \mathrm{d}_{\sigma}{ }^{*}\right)$ transition is also observed at higher energy than the $\mathrm{p}_{\pi} \rightarrow \mathrm{Fe}^{\mathrm{III}} \mathrm{d}_{\pi}$ transition and could be related to the transition at $413 \mathrm{~nm}[35,36]$. The presence of $\mathrm{Fe}^{\mathrm{III}}-\mathrm{Cl}$ bond also allows the presence of LMCT involving chloride $\mathrm{p}_{\pi} \rightarrow \mathrm{Fe}^{\mathrm{III}} \mathrm{d}_{\pi}$ orbitals $[43,44]$.

\subsection{Catalytic Evaluation}

2.3.1. GC-MS. $\mathrm{H}_{2} \mathrm{O}_{2}$ or tert- $\mathrm{BuOOH}$ diluted in solvent $\left(\mathrm{CH}_{3} \mathrm{CN}\right.$ or tert-amylalcohol) was slowly added (within a period of $5 \mathrm{~min}$ ) to a solvent solution containing the catalyst and the substrate, at room temperature $\left(25^{\circ} \mathrm{C}\right)$. For brevity in the text $\left[\mathrm{H}_{2} \mathrm{O}_{2}\right.$ in tert-amylalcohol] will be referred as system $\mathrm{A},\left[\mathrm{H}_{2} \mathrm{O}_{2}\right.$ in $\left.\mathrm{CH}_{3} \mathrm{CN}\right]$ as system $\mathrm{B}$, and [tert- $\mathrm{BuOOH}$ in $\mathrm{CH}_{3} \mathrm{CN}$ ] as system $\mathrm{C}$, respectively. As an internal standard, acetophenone or bromobenzene were used. Catalytic reactions were initiated by adding the oxidant into reaction mixture.

The progress of the reaction was monitored by GC-MS, by removing small samples of the reaction mixture. The yields reported herein are based on the amount of oxidant $\mathrm{H}_{2} \mathrm{O}_{2}$ converted to oxygenated products. To establish the identity of the products unequivocally, the retention times and spectral data were compared to those of commercially available compounds. Blank experiments showed that, without catalyst, no oxidative reactions take place.

\subsubsection{Reaction Conditions}

(1) Optimization of [Oxidant: Substrate] Ratio. To explore the optimum [oxidant-substrate] molar ratio, a first set of catalytic experiments was performed where the amount of substrate was kept constant and the amount of $\mathrm{H}_{2} \mathrm{O}_{2}$ was varied. Subsequently, a second set of catalytic experiments was run for varied amounts of substrate, using the optimum amount of $\mathrm{H}_{2} \mathrm{O}_{2}$ found in the first screening. For this screening, cyclooctene (Figure 1(a)), cyclohexene (Figure 1(b)), styrene (Figure 1(c)), and cyclohexane (Figure 1(d)) were tested. It is noted that $\mathrm{H}_{2} \mathrm{O}_{2}$ was diluted in acetonitrile $(1 / 10 \mathrm{v} / \mathrm{v})$ prior use, and it was introduced into the reaction mixture slowly.

Based on the data of Figures $1(\mathrm{a})-1(\mathrm{~d})$, the higher oxidation yield was obtained by small amounts of $\mathrm{H}_{2} \mathrm{O}_{2}$ and large excess of substrate. This is consistent with the current view that (a) high oxidant concentration causes oxidative destruction of catalyst, (b) large excess of substrate protects the catalyst from oxidative degradation, and, moreover, (c) this substrate large excess minimizes the overoxidation of initial oxidation products [45]. 


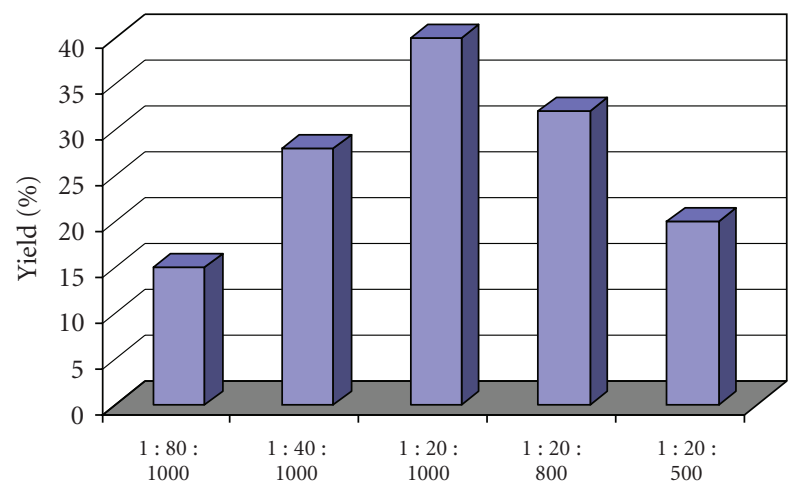

Cis-epoxide cyclooctene

(a)

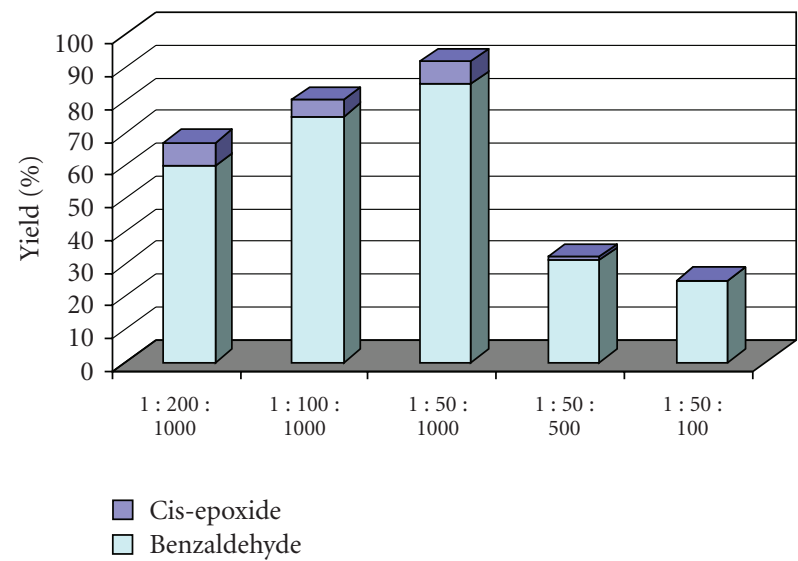

(c)

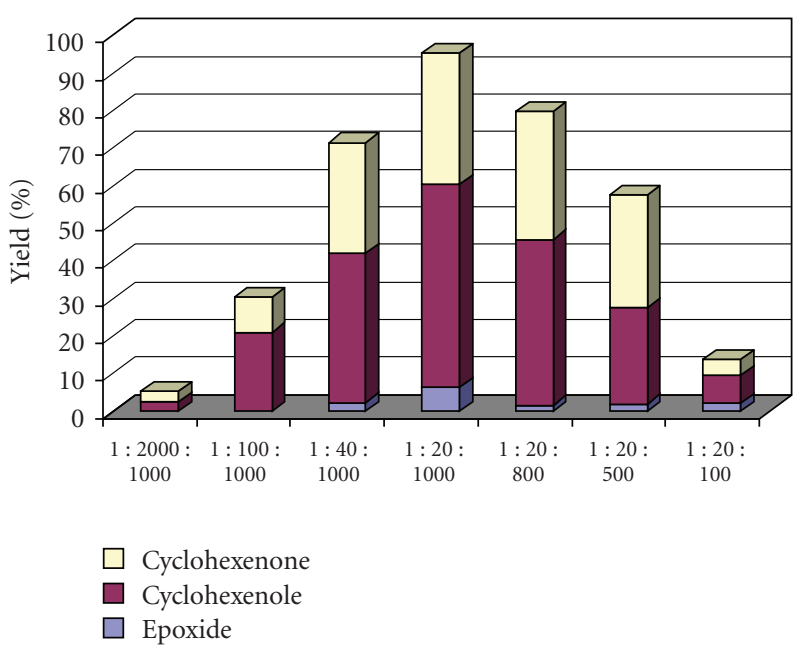

(b)

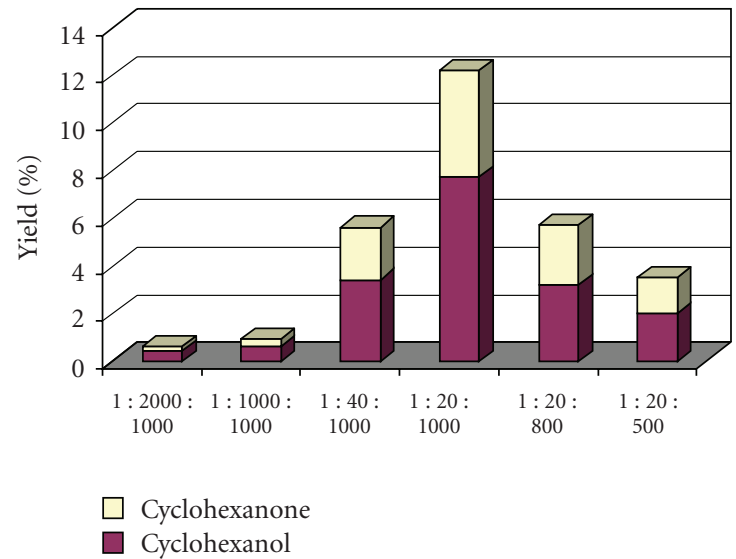

(d)

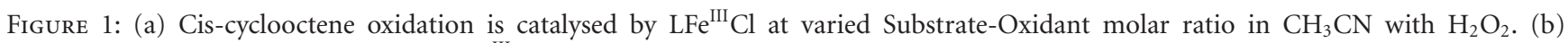
Cyclohexene oxidation is catalysed by $\mathrm{LFe}^{\mathrm{III}} \mathrm{Cl}$ at varied Substrate-Oxidant molar ratio in $\mathrm{CH}_{3} \mathrm{CN}$ with $\mathrm{H}_{2} \mathrm{O}_{2}$. (c) Styrene oxidation is catalysed by $\mathrm{LFe}^{\mathrm{III}} \mathrm{Cl}$ at varied Substrate-Oxidant molar ratio in $\mathrm{CH}_{3} \mathrm{CN}$ with $\mathrm{H}_{2} \mathrm{O}_{2}$. (d) Cyclohexane oxidation is catalysed by $\mathrm{LFe}$ (III $\mathrm{Cl}$ at varied Substrate-Oxidant molar ratio in $\mathrm{CH}_{3} \mathrm{CN}$ with $\mathrm{H}_{2} \mathrm{O}_{2}$. For all figures The given ratio is catalyst : oxidant : substrate.

Based on analogous experiments for all the substrates used in the present study, we found that for cyclohexene, methyl-cyclohexene, cyclooctene, limonene, and cyclohexane oxidation, the optimum molar ratio of [catalyst: oxidant: substrate] was equal to $[1: 20: 1000]$ and for styrene, trans- $\beta$-methyl styrene and cis-stilbene oxidation, this molar ratio was equal to $[1: 50: 1000]$.

(2) Excess of Dioxygen. Iron-based catalysts, in the presence of dioxygen, often adopt radical mechanistic paths. Thus, the $\mathrm{LFe}^{\mathrm{III}} \mathrm{Cl}$ catalyst was evaluated in oxidation reactions with $\mathrm{H}_{2} \mathrm{O}_{2}$, (a) under atmospheric air versus (b) under inert $\mathrm{Ar}$ atmosphere (Table 1, Figure 2).

Based on the data of Table 1, it is observed that (a) the total yield of some oxidation reactions under air was over 100\%; moreover, (b) the total oxidation yield under Ar was decreased. Especially, alcohol and ketone yields were strongly decreased under Ar. This suggests $\mathrm{O}_{2}$-involvement in the oxidation process which possibly propagates a radical autooxidation $[46,47]$ of the more reactive oxygencontaining products such as alcohols and ketones. Thus, to record reliable data, all catalytic experiments herein were performed under a vigorous Ar purge to avoid any trace of $\mathrm{O}_{2}$.

(3) Solvent Effect on the Reaction Time. The time course profiles of the $\mathrm{LFe}^{\mathrm{III}} \mathrm{Cl}$-catalysed oxidation of cyclohexene with $\mathrm{H}_{2} \mathrm{O}_{2}$ in $\mathrm{CH}_{3} \mathrm{CN}$ and in tert-amylalcohol are given in Figure 3. According to these data the catalytic reaction was practically accomplished within $4 \mathrm{~h}$ in $\mathrm{CH}_{3} \mathrm{CN}$ and within $12 \mathrm{~h}$ in tert-amylalcohol. Thus, the reaction rate is strongly influenced by solvent. This effect could be related to the solvent polarity. However, in both solvents, the total yield of cyclohexene oxidation is quite high providing $88.5 \%$ in $\mathrm{CH}_{3} \mathrm{CN}$ and $79.0 \%$ in tert-amylalcohol. It is noted that cyclohexene oxidation, in $\mathrm{CH}_{3} \mathrm{CN}$ with tert-BuOOH as oxidant, was complete within $2 \mathrm{~h}$, resulting in a $76.3 \%$ total yield. 
TABLE 1: Hydrocarbon oxidations catalyzed by $\mathrm{LFeCl}$ with $\mathrm{H}_{2} \mathrm{O}_{2}$ in $\mathrm{CH}_{3} \mathrm{CN}$ under atmospheric air and under Ar.

\begin{tabular}{|c|c|c|c|c|c|}
\hline substrate & products & $\begin{array}{c}\mathrm{LFeCl} \\
\text { under } \mathrm{Ar}^{\mathrm{c}} \\
\text { Yield }(\%)\end{array}$ & $\begin{array}{c}\mathrm{LFeCl} \\
\text { under } \mathrm{Ar}^{\mathrm{c}} \\
\text { Total yield } \\
(\%)\end{array}$ & $\begin{array}{c}\text { LFeCl } \\
\text { under air } \\
\text { Yield (\%) }\end{array}$ & $\begin{array}{c}\mathrm{LFeCl} \\
\text { under air } \\
\text { Total yield } \\
(\%)\end{array}$ \\
\hline \multirow{3}{*}{ Cyclohexene $^{\mathrm{a}}$} & cis-epoxide & 6.5 & & 3.5 & \\
\hline & 2-cyclohexenol & 52.0 & & 61.5 & \\
\hline & 2-cyclohexenone & 30.0 & 88.5 & 43.2 & 108.2 \\
\hline \multirow{4}{*}{ 1-Methyl-cyclohexene ${ }^{a}$} & cis-epoxide & 20.0 & & 21.0 & \\
\hline & 1-methyl-2-cyclohexen-1-ol & 25.6 & & 22.6 & \\
\hline & 3-methyl-2-cyclohexen-1-ol & 42.0 & & 45.3 & \\
\hline & 3-methyl-2-cyclohexen-1-one & 8.8 & 96.4 & 52.0 & 140.9 \\
\hline Cyclooctene $^{\mathrm{a}}$ & cis- epoxide & 37.0 & 37.0 & 41.0 & 41.0 \\
\hline \multirow{3}{*}{ Styrene $\mathrm{e}^{\mathrm{b}}$} & epoxide & 7.5 & & 7.0 & \\
\hline & phenyl-acetaldehyde & 7.0 & & 3.5 & \\
\hline & benzaldehyde & 35.0 & 49.5 & 94.5 & 105.0 \\
\hline \multirow{3}{*}{ Methyl-Styrene ${ }^{b}$} & trans-epoxide & 41.9 & & 29.0 & \\
\hline & methyl-benzyl-ketone & 11.3 & & 2.0 & \\
\hline & benzaldehyde & 40.0 & 93.2 & 90.0 & 121.0 \\
\hline \multirow{2}{*}{ Cis- stylbene ${ }^{b}$} & cis-epoxide & 15.8 & & 6.0 & \\
\hline & benzaldehyde & 36.0 & 51.8 & 36.0 & 42.0 \\
\hline
\end{tabular}

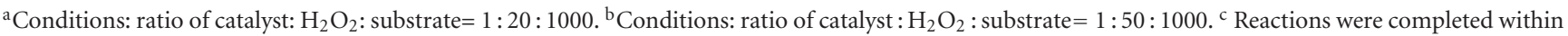
$4 \mathrm{~h}$.

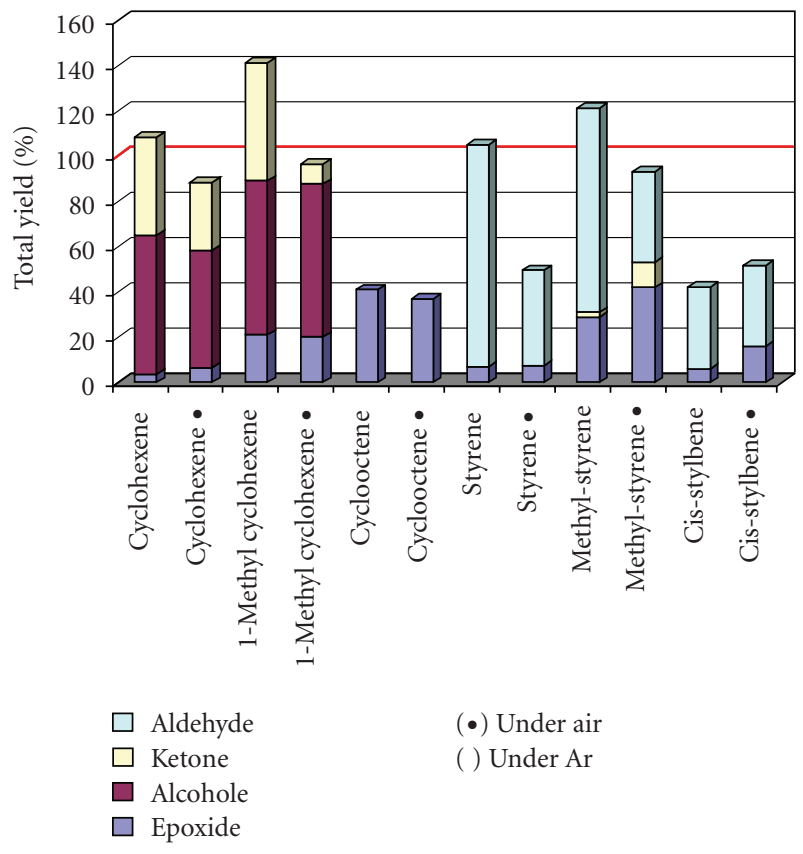

FIGURE 2: Bar chart representation of oxidations catalyzed by $\mathrm{LFe}{ }^{\mathrm{III}} \mathrm{Cl}$ with $\mathrm{H}_{2} \mathrm{O}_{2}$ in $\mathrm{CH}_{3} \mathrm{CN}$ under atmospheric air and under Ar.

\section{Results and Discussion}

3.1. Hydrocarbon Oxidation by the Fe $\mathrm{FII}^{I I}$-Catalysts. The catalytic activity of $\mathrm{LFe}^{\mathrm{III}} \mathrm{Cl}$ for hydrocarbon oxidation was evaluated using tert-BuOOH and $\mathrm{H}_{2} \mathrm{O}_{2}$ as oxidants in

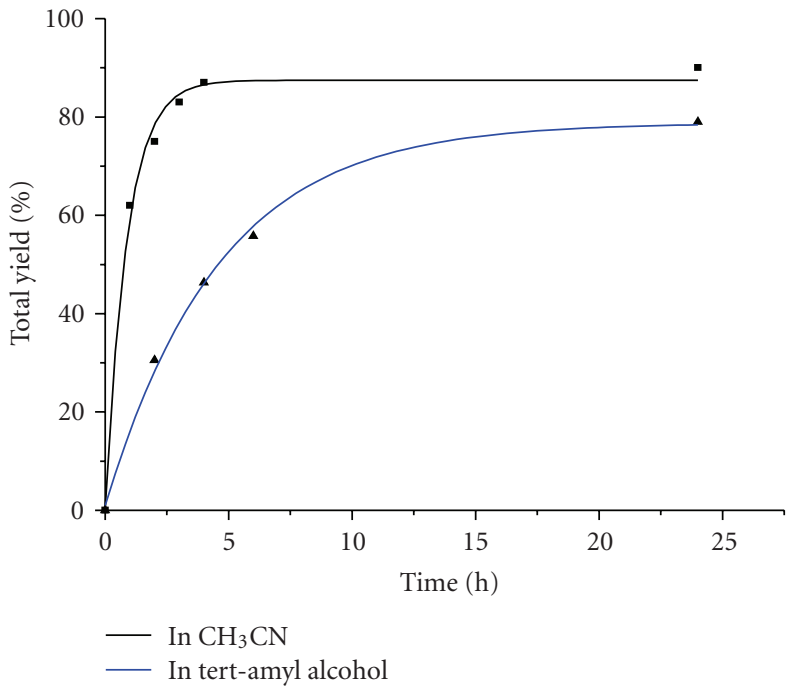

FIGURE 3: Time-dependent reaction profiles for cyclohexene oxidation catalysed by $\mathrm{LFe}{ }^{\mathrm{III}} \mathrm{Cl}$ with $\mathrm{H}_{2} \mathrm{O}_{2}$ in $\mathrm{CH}_{3} \mathrm{CN}$ and tertamylalcohol.

either $\mathrm{CH}_{3} \mathrm{CN}$ or tert-amylalcohol. Cyclohexene, methylcyclohexene, cyclooctene, limonene, and cyclohexane were used as substrates with a ratio of catalyst: oxidant: substrate equal to $1: 20: 1000$ and styrene, trans- $\beta$-methyl styrene and cis-stilbene with a ratio of catalyst: oxidant: substrate equal to $1: 50: 1000$. All oxidation reactions were carried out at room temperature under Ar atmosphere as described in details in Experimental Section. The obtained catalytic 


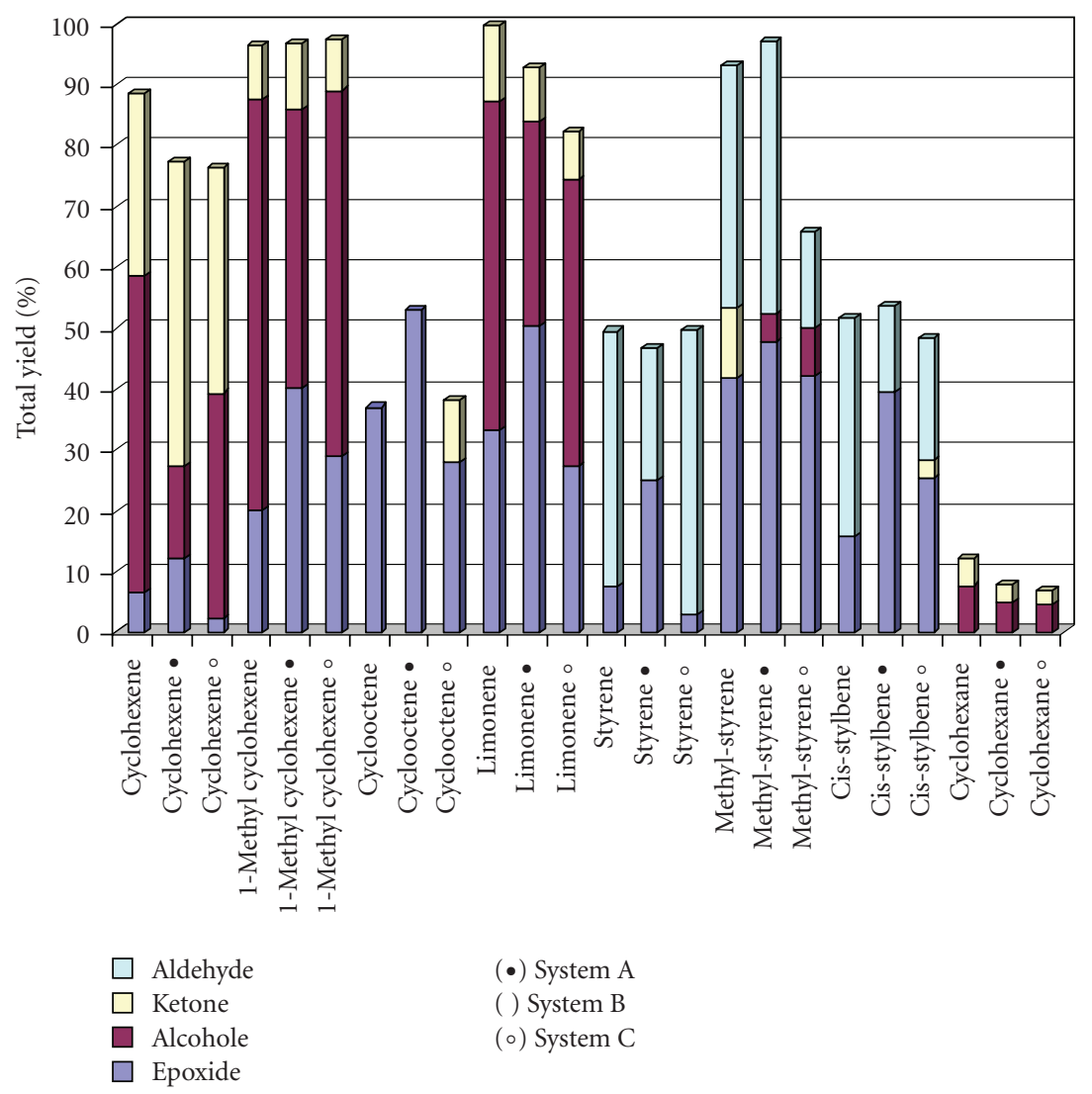

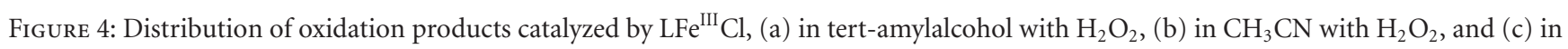
$\mathrm{CH}_{3} \mathrm{CN}$ with tert-BuOOH. See Table 2 for further details.

results are summarized in Table 2. Figure 4 provides a histogram-plot of the data of Table 2. The catalytic data of LFe ${ }^{\text {III }} \mathrm{Cl}$ with $\mathrm{H}_{2} \mathrm{O}_{2}$ in $\mathrm{CH}_{3} \mathrm{CN}$ were taken from [38] and are included here for comparison.

Based on Table 2 we observe that cyclohexene and limonene oxidation catalyzed by the $\mathrm{LFeCl}$ provided oxidation products with a combined yield of $79.0 \%$ and $93.7 \%$, respectively, in tert-amylalcohol with $\mathrm{H}_{2} \mathrm{O}_{2}$ (system A), $88.5 \%$ and $99.8 \%$ in $\mathrm{CH}_{3} \mathrm{CN}$ with $\mathrm{H}_{2} \mathrm{O}_{2}$ (system $\mathrm{B}$ ), and $76.3 \%$ and $82.34 \%$ in $\mathrm{CH}_{3} \mathrm{CN}$ with tert-BuOOH (system C). Cyclohexene undergoes mainly allylic oxidation forming 2-cyclohexene-1-ol and 2-cyclohexene-1-one (with yields $16.0 \%$ and $50.7 \%$, resp., by system $\mathrm{A}, 52.0 \%$ and $30.0 \%$ by system B, and $37.0 \%$ and $37.0 \%$ by system C). However cyclohexene epoxidation is also observed, providing low epoxide yields $12.3 \%, 6.5 \%$, and $2.3 \%$ by systems A, B, and $\mathrm{C}$, respectively. It is note that in tert-amylalcohol, the yield of epoxide and ketone increases, while the alcohol yield is reduced.

The major products detected from limonene oxidation were (i) two epoxides (cis- and trans-) derived from epoxidation of the electron-rich double bond at 1,2- position and (ii) alcohols derived from hydroxylation of the double bond at 1 - and 2-position and from hydroxylation at 6-position closed to 1,2-double bond. Oxidation products from the more accessible, though less electron-rich, double bond at 8,9-position were not observed. Additionally, considerable amounts of the corresponding ketone at 6-position were also formed. In summary, the yield (a) of limonene-epoxides (cis1,2 and trans-1,2) was found to be $51.2 \%$ in system A, 33.3\% in system $\mathrm{B}$, and $27.4 \%$ in system $\mathrm{C}$, (b) of limonene-alcohols (1-ol, 2-ol, and 6-ol) 33.5\%, 54.0\%, and 46.9\%, respectively and (c) of 6-ketone $9.0 \%, 12.5 \%$, and $8 \%$ in systems A, B, and $\mathrm{C}$ respectively. These data provide a total catalytic oxidation of limonene $93.7 \%, 99.8 \%$, and $82.3 \%$ achieved by $\mathrm{LFeCl}$, respectively, in tert-amylalcohol with $\mathrm{H}_{2} \mathrm{O}_{2}$ (system $A$ ), in $\mathrm{CH}_{3} \mathrm{CN}$ with $\mathrm{H}_{2} \mathrm{O}_{2}$ (system $\mathrm{B}$ ), and in $\mathrm{CH}_{3} \mathrm{CN}$ with tert$\mathrm{BuOOH}$ (system C).

When methyl-cyclohexene was used as substrate, the detected oxidation products were cis-epoxide, 1-methyl-2cyclohexen-1-ol, 3-methyl-2-cyclohexen-1-ol, and 3-methyl2-cyclohexen-1-one. The corresponding yields found to be [40.0\%, 20.0\%, and 29.0\%], [21.3\%, 25.6\%, and 23.7\%], [24.5\% 42.0\%, and 36.3\%], and [10.9\%, 8.8\%, and 8.5\%] in catalytic systems $\mathrm{A}, \mathrm{B}$, and $\mathrm{C}$, respectively. Generally, methyl-substituted alkenes are more reactive towards both epoxidation and allylic oxidation. Our findings confirm this aspect providing total yield of methyl-cyclohexene oxidation $93.7 \%, 98.8 \%$, and $83.3 \%$ by the present catalytic systems.

Cis-cyclooctene as substrate afforded a single-product reaction with $\mathrm{H}_{2} \mathrm{O}_{2}$ catalysed by $\mathrm{LFe}{ }^{\mathrm{III}} \mathrm{Cl}$ resulting only in 
TABLE 2: Hydrocarbon oxidation by $\mathrm{LF} e^{I I I} \mathrm{Cl}$ catalyst.

\begin{tabular}{|c|c|c|c|c|c|c|c|}
\hline \multirow{2}{*}{ substrate } & \multirow{2}{*}{ products } & \multicolumn{2}{|c|}{$\mathrm{LFeCl}^{\mathrm{c}}$} & \multicolumn{2}{|c|}{$\mathrm{LFeCl}^{\mathrm{d}}$} & \multicolumn{2}{|c|}{$\mathrm{LFeCl}^{\mathrm{e}}$} \\
\hline & & Yield (\%) & Total yield (\%) & Yield (\%) & Total yield (\%) & Yield $(\%)$ & Total yield $(\%)$ \\
\hline \multirow{3}{*}{ Cyclohexene $^{\mathrm{a}}$} & cis-epoxide & 12.3 & & 6.5 & & 2.3 & \\
\hline & 2-cyclohexenol & 16.0 & & 52.0 & & 37.0 & \\
\hline & 2-cyclohexenone & 50.7 & 79.0 & 30.0 & 88.5 & 37.0 & 76.3 \\
\hline \multirow{4}{*}{ 1-Methyl-cyclohexene ${ }^{a}$} & cis-epoxide & 40.0 & & 20.0 & & 29.0 & \\
\hline & $\begin{array}{l}\text { 1-methyl-2-cyclohexen- } \\
1 \text {-ol }\end{array}$ & 21.3 & & 25.6 & & 23.7 & \\
\hline & $\begin{array}{l}\text { 3-methyl-2-cyclohexen- } \\
\text { 1-ol }\end{array}$ & 24.5 & & 42.0 & & 36.3 & \\
\hline & $\begin{array}{l}\text { 3-methyl-2-cyclohexen- } \\
\text { 1-one }\end{array}$ & 10.9 & 96.7 & 8.8 & 96.4 & 8.5 & 97.5 \\
\hline \multirow{2}{*}{ Cyclooctene $^{\mathrm{a}}$} & cis- epoxide & 53.0 & & 37.0 & & 28.0 & \\
\hline & 2-cyclooctenone & - & 53.0 & & 37.0 & 10.0 & 38.0 \\
\hline \multirow{4}{*}{ Limonene $^{\mathrm{a}}$} & cis-1,2 epoxide & 34.4 & & 21.0 & & 18.0 & \\
\hline & trans-1,2 epoxide & 16.8 & & 12.3 & & 9.4 & \\
\hline & limonene alcohol $^{\mathrm{f}}$ & $33.5^{\mathrm{h}}$ & & $54.0^{\mathrm{g}}$ & & $46.9^{\mathrm{i}}$ & \\
\hline & limoneme ketonej & 9.0 & 93.7 & 12.5 & 99.8 & 8.0 & 82.3 \\
\hline \multirow{3}{*}{ Styrene $^{\mathrm{b}}$} & epoxide & 25.0 & & 7.5 & & 3.0 & \\
\hline & phenyl-acetaldehyde & 1.6 & & 7.0 & & 1.6 & \\
\hline & benzaldehyde & 20.0 & 46.6 & 35.0 & 49.5 & 45.0 & 49.6 \\
\hline \multirow{4}{*}{ Methyl-styrene ${ }^{\mathrm{b}}$} & trans-epoxide & 47.7 & & 41.9 & & 42.0 & \\
\hline & methyl-benzyl-alcohole & 4.5 & & - & & 8.0 & \\
\hline & methyl-benzyl-ketone & - & 11.3 & & - & & \\
\hline & benzaldehyde & 45.0 & 97.2 & 40.0 & 93.2 & 15.8 & 65.8 \\
\hline \multirow{4}{*}{ Cis-stylbene ${ }^{\mathrm{b}}$} & cis-epoxide & 9.5 & & 15.8 & & 2.4 & \\
\hline & trans-epoxide & 30.0 & & - & & 23.0 & \\
\hline & stylben-cetone & - & & - & & 3.0 & \\
\hline & benzaldehyde & 14.0 & 53.5 & 36.0 & 51.8 & 20.0 & 48.4 \\
\hline \multirow{2}{*}{ Cyclohexane ${ }^{a}$} & cyclohexanol & 5.0 & & 7.7 & & 4.6 & \\
\hline & cyclohexanone & 3.0 & 8.0 & 4.4 & 12.1 & 2.4 & 7.0 \\
\hline
\end{tabular}

${ }^{\mathrm{a}}$ Conditions: ratio of catalyst $:$ oxidant $:$ substrate $=1: 20: 1000 .{ }^{\mathrm{b}}$ Conditions: ratio of catalyst $:$ oxidant $:$ substrate $=1: 50: 1000 .{ }^{\mathrm{c}}$ Reactions were completed within $12 \mathrm{~h}$ in tert-amylalcohol with $\mathrm{H}_{2} \mathrm{O}_{2}$ as oxidant. ${ }^{\mathrm{d}}$ Reactions were completed within $4 \mathrm{~h}$ in $\mathrm{CH}_{3} \mathrm{CN}$ with $\mathrm{H}_{2} \mathrm{O}_{2}$ as oxidant. ${ }^{\mathrm{e}}$ Reactions were completed within. $1 \mathrm{~h}$ in $\mathrm{CH}_{3} \mathrm{CN}$ with tert-BuOOH as oxidant. ${ }^{\mathrm{f}} \mathrm{Limonene}$ alcohols were found to be a mixture of 1-ol, 2-ol, and 6-ol. ${ }^{8} 54 \%$ yield corresponds to $23 \%$ for 1 -ol, $13.5 \%$ for 2 -ol, and $17.5 \%$ for 6 -ol. ${ }^{\mathrm{h}} 33.5 \%$ yield corresponds to $9.0 \%$ for 1 -ol, $6.5 \%$ for 2 -ol, and $18.0 \%$ for 6 -ol. ${ }^{\mathrm{i}} 46.9$ yield corresponds to $26.0 \%$ for 1 -ol, $8.97 \%$ for 2 -ol, and $11.93 \%$ for 6 -ol. ${ }^{j}$ The only observed ketone is the 6-one.

cis-cyclooctene epoxide with $53.0 \%$ and $37.0 \%$ yields in systems $\mathrm{A}$ and $\mathrm{B}$, respectively. However, the use of tert$\mathrm{BuOOH}$ as oxidant provided $28 \%$ epoxide and $10 \% 2$ cyclooctenone. Generally, cyclooctene occurs more readily epoxydation than allylic oxidation; however, here with tert$\mathrm{BuOOH}$, overoxidized 2-cyclooctenone derived from allylic oxidation was also detected.

Cis-stilbene oxidation in catalytic systems $\mathrm{A}$ and $\mathrm{C}$ provided cis- and trans- epoxides as major products $[9.5 \%$ and $30 \%$ in system A] and $[2.4 \%$ and $23.0 \%$ in C]. Benzaldehyde as oxidative cleavage product was also formed with yields $14 \%$ and $20 \%$, respectively. In Catalytic system B, the detected products were benzaldehyde with yield $36.0 \%$ and cis-stilbene epoxide with yields $15.8 \%$.
Styrene oxidation provided benzaldehyde as major product derived by oxidative cleavage of the exo-cyclic double bond with yields $20.0 \%, 35.0 \%$, and $45.0 \%$ in systems $\mathrm{A}, \mathrm{B}$, and $\mathrm{C}$, respectively. However, epoxide and phenyl acetaldehyde have been also formed by direct oxidation of the same double bond with $[25.0 \%$ and $1.6 \%]$ in system $\mathrm{A},[7.5 \%$ and $7.0 \%]$ in system $\mathrm{B}$, and [3.0\% and $1.6 \%$ ] in system C. Overall, styrene was oxidised by $\mathrm{LFe}^{\mathrm{III}} \mathrm{Cl}$ in different oxidation conditions providing total yields from $46.6 \%$ to $49.6 \%$.

The methyl-substituted styrene, trans- $\beta$-methyl styrene, is more reactive than styrene showing total oxidation yields $97.2 \%, 93.2 \%$, and $65.8 \%$ in catalytic systems A, B, and $\mathrm{C}$, respectively. The identified products were trans-epoxide 
$(47.7 \%, 41.9 \%$, and $42.0 \%)$ and benzaldehyde as oxidation cleavage adduct $(45.0 \%, 40.0 \%$, and $15.8 \%)$. In some cases, methyl-benzyl-ketone and methyl-benzyl-alcohol were also detected.

Finally, cyclohexane oxidation by the present $\mathrm{Fe}^{\mathrm{III}}$ catalyst, in the three $\mathrm{A}, \mathrm{B}$, and $\mathrm{C}$ catalytic conditions, gave cyclohexanol and cyclohexanone with combined yields $8.0 \%$, $12.2 \%$, and $7.0 \%$ while the corresponding alcohol/ketone $(\mathrm{A} / \mathrm{K})$ ratio was found to be $1.66,1.75$, and 1.71 , respectively.

3.2. Mechanistic Considerations. The $\mathrm{A} / \mathrm{K}$ ratio in cyclohexane can be used as a criterion of the presence and lifetime of free alkyl radical intermediates [31] as follows: (i) when $\mathrm{A} / \mathrm{K}=1$, then we assume that the alkyl radicals are longlived with a strong tendency to interact with $\mathrm{O}_{2}$ to form alkyl-peroxy-radicals [45]. At the end, following a Russelltype terminal stage [48], recombination of these radicals results in the formation of equimolar amounts of alcohol and ketone $[21,31]$. (ii) When $\mathrm{A} / \mathrm{K}>1$, the radical ${ }^{\bullet} \mathrm{OH}$ is formed by a metal-based system and the metal center reacts directly to form the corresponding alcohol. This is consistent with the formation of $\mathrm{Fe}^{\mathrm{III}}-\mathrm{OOH}$ intermediate and the homolytic cleavage of $\mathrm{O}-\mathrm{O}$ bond to ${ }^{*} \mathrm{HO}$ radical and oxoiron(IV) followed by electrophilic addition of metalbased species to the substrate.

Hydrocarbon oxidations catalyzed by $\mathrm{LFe}^{\mathrm{III}} \mathrm{Cl}$ presented comparable selectivity and distribution of oxidation products, in the three experimental conditions studied herein. This implies similar mechanistic path in the catalysis. Generally, $\mathrm{LFe}{ }^{\mathrm{III}} \mathrm{Cl}$ is able to generate iron-hydroperoxo-species under the mild oxidation conditions used. It is known from other nonheme iron systems that $\mathrm{Fe}^{\mathrm{III}}-\mathrm{OOH}$ could be either (a) a precursor or (b) itself an oxidant $[22,28,46]$. In the first case, possible homolytic cleavage of $\mathrm{O}-\mathrm{O}$ bond leads to an $\mathrm{Fe}^{\mathrm{IV}}=\mathrm{O}$ species and reactive ${ }^{\bullet} \mathrm{HO}$ radical while a heterolytic cleavage generates an $\mathrm{Fe}^{\mathrm{v}}=\mathrm{O}$ and an $\mathrm{OH}^{-}$species $[22,28$, 46]. Herein, the major oxidation products of alkenes are alcohols and ketones, mainly derived by an allylic oxidation reaction. However, considerable amounts of epoxides have been also formed. Taking into account that the detected allylic oxidation products are the main component of the observed oxidation yield, a dominant radical mechanistic path is suggested. This suggestion is further supported by detection of traces of the compounds illustrated in Scheme 2. Their formation could be a result of (a) interaction between two allyl-radicals formed on substrates and (b) interaction of an allyl-radical on substrate and a hydro-peroxo radical.

In this context, when tert-amylalcohol-a less polar solvent-was used with $\mathrm{H}_{2} \mathrm{O}_{2}$, the reaction time is considerably longer, the yield of the corresponding epoxides increased, and the yield of radical mechanism products, that is, alcohols and ketones decreases. On the other hand, the use of tert-BuOOH as oxidant enhanced the yield of the corresponding alcohols and ketones.

\section{Conclusion}

The $\mathrm{LFe}^{\mathrm{III}} \mathrm{Cl}$ catalyst was efficient in homogeneous hydrocarbon oxidations providingsignificant yields. The catalytic

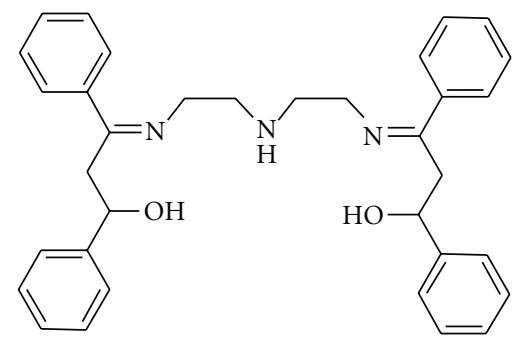

Scheme 1: Schematic representation of ligand [3-\{2-[2-(3hydroxy-1,3-diphenyl-allylideneamino)-ethylamino]-ethylimino 1,3-diphenyl-propen-1-ol] (L).
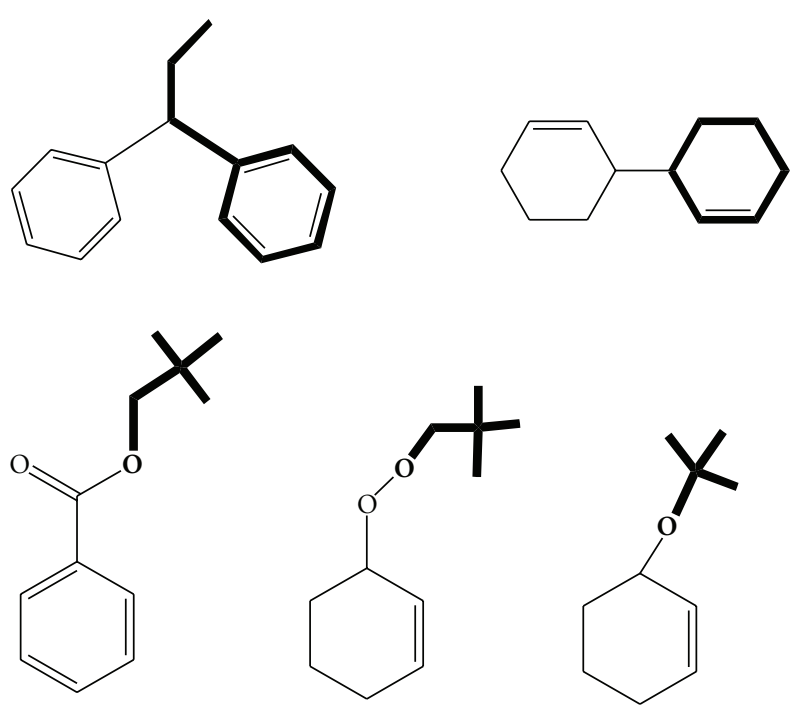

Scheme 2: Schematic representation of detected byproducts.

experiments (a) were performed under inert argon atmosphere excluding any trace of $\mathrm{O}_{2}$ which favors radical oxidation paths and (b) included large excess of substrate, protecting the catalyst from oxidative degradation and minimizing the overoxidation of initial oxidation products. tert- $\mathrm{BuOOH}$ provided comparable oxidation yields with $\mathrm{H}_{2} \mathrm{O}_{2}$; nevertheless it slightly favors the formation of alcohols and ketones versus epoxides. The polarity of solvent strongly influences the reaction rate and the nature of oxidation products. We suggest that $\mathrm{LFe}^{\mathrm{III}} \mathrm{Cl}$ functions via the formation of iron-hydroperoxo-species and the dominant mechanistic path is a radical one.

\section{References}

[1] K. Furuhashi, "Biological routes to optically active epoxides," in Chirality in Industry, A. N. Collins, G. N. Sheldrake, and J. Crosby, Eds., pp. 167-186, John Wiley \& Sons, London, UK, 1992.

[2] U. Sundermeier, C. Döbler, and M. Beller, "Recent developments in the osmium-catalyzed dihydroxylation of olefins," in Modern Oxidation Methods, J. E. Bäckvall, Ed., p. 1, WileyVCH, Weinheim, Germany, 2004. 
[3] M. Costas, M. P. Mehn, M. P. Jensen, and L. Que Jr., "Dioxygen activation at mononuclear nonheme iron active sites: enzymes, models, and intermediates," Chemical Reviews, vol. 104, no. 2, pp. 939-986, 2004.

[4] R. Mas-Ballesté, M. Costas, T. Van Den Berg, and L. Que Jr., "Ligand topology effects on olefin oxidations by bio-inspired $\left[\mathrm{Fe}^{\mathrm{II}}\left(\mathrm{N}_{2} \mathrm{Py}_{2}\right)\right]$ catalysts," Chemistry-A European Journal, vol. 12, no. 28, pp. 7489-7500, 2006.

[5] K. Shikama, "The molecular mechanism of autoxidation for myoglobin and hemoglobin: a venerable puzzle," Chemical Reviews, vol. 98, no. 4, pp. 1357-1373, 1998.

[6] M. Merkx, D. A. Kopp, M. H. Sazinsky, J. L. Blazyk, J. Müller, and S. J. Lippard, "Dioxygen activation and methane hydroxylation by soluble methane monooxygenase: a tale of two irons and three proteins," Angewandte Chemie International Edition, vol. 40, no. 15, pp. 2782-2807, 2001.

[7] S. C. Pulver, W. A. Froland, J. D. Lipscomb, and E. I. Solomon, "Ligand field circular dichroism and magnetic circular dichroism studies of component B and substrate binding to the hydroxylase component of methane monooxygenase," Journal of the American Chemical Society, vol. 119, no. 2, pp. 387-395, 1997.

[8] M. D. Wolfe, J. V. Parales, D. T. Gibson, and J. D. Lipscomb, "Single turnover chemistry and regulation of $\mathrm{O}_{2}$ activation by the oxygenase component of naphthalene 1,2-dioxygenase," Journal of Biological Chemistry, vol. 276, no. 3, pp. 1945-1953, 2001.

[9] A. Karlsson, J. V. Parales, R. E. Parales, D. T. Gibson, H. Eklund, and S. Ramaswamy, "Crystal structure of naphthalene dioxygenase: side-on binding of dioxygen to iron," Science, vol. 299, no. 5609, pp. 1039-1042, 2003.

[10] R. H. Holm, P. Kennepohl, and E. I. Solomon, "Structural and functional aspects of metal sites in biology," Chemical Reviews, vol. 96, no. 7, pp. 2239-2314, 1996.

[11] V. K. Sivasubramanian, M. Ganesan, S. Rajagopal, and R. Ramaraj, "Iron(III)-salen complexes as enzyme models: mechanistic study of oxo(salen)iron complexes oxygenation of organic sulfides," Journal of Organic Chemistry, vol. 67, no. 5, pp. 1506-1514, 2002.

[12] X. Shan and L. Que Jr., "High-valent nonheme iron-oxo species in biomimetic oxidations," Journal of Inorganic Biochemistry, vol. 100, no. 4, pp. 421-433, 2006.

[13] K. C. Gupta, A. Kumar Sutar, and C.-C. Lin, "Polymersupported Schiff base complexes in oxidation reactions," Coordination Chemistry Reviews, vol. 253, no. 13-14, pp. 1926-1946, 2009.

[14] R. B. Bedford, D. W. Bruce, R. M. Frost, J. W. Goodby, and M. Hird, "Iron(III) salen-type catalysts for the cross-coupling of aryl Grignards with alkyl halides bearing $\beta$-hydrogens," Chemical Communications, no. 24, pp. 2822-2823, 2004.

[15] K. P. Bryliakov and E. P. Talsi, "Evidence for the formation of an iodosylbenzene(salen)iron active intermediate in a (salen)iron(III)-catalyzed asymmetric sulfide oxidation," Angewandte Chemie International Edition, vol. 43, no. 39, pp. 5228-5230, 2004.

[16] L. Que Jr. and W. B. Tolman, "Recurring structural motifs in bioinorganic chemistry," in Bio-Coordination Chemistry, J. A. McCleverty and T. J. Meyer, Eds., vol. 8 of Comprehensive Coordination Chemistry II, Elsevier, Oxford, UK, 2004.

[17] E. Y. Tshuva and S. J. Lippard, "Synthetic models for non-heme carboxylate-bridged diiron metalloproteins: strategies and tactics," Chemical Reviews, vol. 104, no. 2, pp. 987-1012, 2004.
[18] A. L. Feig and S. J. Lippard, "Reactions of non-heme iron(II) centers with dioxygen in biology and chemistry," Chemical Reviews, vol. 94, no. 3, pp. 759-805, 1994.

[19] C. He and Y. Mishina, "Modeling non-heme iron proteins," Current Opinion in Chemical Biology, vol. 8, no. 2, pp. 201-208, 2004.

[20] J.-U. Rohde, M. R. Bukowski, and L. Que Jr., "Functional models for mononuclear nonheme iron enzymes," Current Opinion in Chemical Biology, vol. 7, no. 6, pp. 674-682, 2003.

[21] K. Chen and L. Que Jr., "Evidence for the participation of a high-valent iron-oxo species in stereospecific alkane hydroxylation by a non-heme iron catalyst," Chemical Communications, no. 15, pp. 1375-1376, 1999.

[22] M. Costas, A. K. Tipton, K. Chen, D.-H. Jo, and L. Que Jr., "Modeling rieske dioxygenases: the first example of iron-catalyzed asymmetric cis-dihydroxylation of olefins," Journal of the American Chemical Society, vol. 123, no. 27, pp. 6722-6723, 2001.

[23] K. Chen, M. Costas, J. Kim, A. K. Tipton, and L. Que Jr., "Olefin cis-dihydroxylation versus epoxidation by non-heme iron catalysts: two faces of an FeIII-OOH coin," Journal of the American Chemical Society, vol. 124, no. 12, pp. 3026-3035, 2002.

[24] P. D. Oldenburg, A. A. Shteinman, and L. Que Jr., "Ironcatalyzed olefin cis-dihydroxylation using a bio-inspired N,N, O-ligand," Journal of the American Chemical Society, vol. 127, no. 45, pp. 15672-15673, 2005.

[25] C. P. Horwitz, D. R. Fooksman, L. D. Vuocolo, S. W. Gordon-Wylie, N. J. Cox, and J. T. Collins, "Ligand design approach for securing robust oxidation catalysts," Journal of the American Chemical Society, vol. 120, pp. 4867-4868, 1998.

[26] T. J. Collins, "TAML oxidant activators: a new approach to the activation of hydrogen peroxide for environmentally significant problems," Accounts of Chemical Research, vol. 35, no. 9, pp. 782-790, 2002.

[27] J. M. Rowland, M. Olmstead, and P. K. Mascharak, "Syntheses, structures, and reactivity of low spin iron(III) complexes containing a single carboxamido nitrogen in a [FeN5L] chromophore," Inorganic Chemistry, vol. 40, no. 12, pp. 2810-2817, 2001.

[28] M. Klopstra, G. Roelfes, R. Hage, R. M. Kellogg, and B. L. Feringa, "Non-heme iron complexes for stereoselective oxidation: tuning of the selectivity in dihydroxylation using different solvents," European Journal of Inorganic Chemistry, vol. 4, pp. 846-856, 2004.

[29] F. G. Gelalcha, G. Anilkumar, M. K. Tse, A. Brückner, and M. Beller, "Biomimetic iron-catalyzed asymmetric epoxidation of aromatic alkenes by using hydrogen peroxide," Chemistry-A European Journal, vol. 14, no. 25, pp. 7687-7698, 2008.

[30] L. Que Jr. and R. Y. N. Ho, "Dioxygen activation by enzymes with mononuclear non-heme iron active sites," Chemical Reviews, vol. 96, no. 7, pp. 2607-2624, 1996.

[31] M. Costas, K. Chen, and L. Que Jr., "Biomimetic nonheme iron catalysts for alkane hydroxylation," Coordination Chemistry Reviews, vol. 200-202, pp. 517-544, 2000.

[32] M. Lubben, A. Meetsma, E. C. Wilkinson, B. Feringa, and L. Que Jr., "Nonheme iron centers in oxygen activation: characterization of an iron(III) hydroperoxide intermediate," Angewandte Chemie International Edition in English, vol. 34, no. 13-14, pp. 1512-1514, 1995. 
[33] I. Bernal, I. M. Jensen, K. B. Jensen, C. J. McKenzie, H. Toftlund, and J. Tuchagues, "Iron(II) complexes of polydentate aminopyridyl ligands and an exchangeable sixth ligand; Reactions with peroxides," Journal of the Chemical Society, Dalton Transactions, no. 22, pp. 3667-3675, 1995.

[34] J. Kim, E. Larka, E. C. Wilkinson, and L. Que Jr., "An alkylperoxoiron(III) intermediate and its role in the oxidation of aliphatic C-H Bonds," Angewandte Chemie (International Edition in English), vol. 34, no. 18, pp. 2048-2051, 1995.

[35] B. J. Wallar and J. D. Lipscomb, "Dioxygen activation by enzymes containing binuclear non-heme iron clusters," Chemical Reviews, vol. 96, no. 7, pp. 2625-2657, 1996.

[36] M. Louloudi, K. Mitopoulou, E. Evaggelou, Y. Deligiannakis, and N. Hadjiliadis, "Homogeneous and heterogenized copper(II) complexes as catechol oxidation catalysts," Journal of Molecular Catalysis A, vol. 198, no. 1-2, pp. 231-240, 2003.

[37] C. Vartzouma, E. Evaggellou, Y. Sanakis, N. Hadjiliadis, and M. Louloudi, "Alkene epoxidation by homogeneous and heterogenised manganese(II) catalysts with hydrogen peroxide," Journal of Molecular Catalysis A, vol. 263, no. 1-2, pp. 77-85, 2007.

[38] G. Bilis, K. C. Christoforidis, Y. Deligiannakis, and M. Louloudi, "Hydrocarbon oxidation by homogeneous and heterogeneous non-heme iron (III) catalysts with $\mathrm{H}_{2} \mathrm{O}_{2}$," Catalysis Today. In press.

[39] G. Grigoropoulou, K. C. Christoforidis, M. Louloudi, and Y. Deligiannakis, "Structure-catalytic function relationship of $\mathrm{SiO}_{2}$-immobilized mononuclear $\mathrm{Cu}$ complexes: an EPR study," Langmuir, vol. 23, no. 20, pp. 10407-10418, 2007.

[40] D. P. E. Dickson and F. J. Berry, Mossbauer Spectroscopy, Cambridge University Press, Cambridge, UK, 1996.

[41] J. Peisach, W. E. Blumberg, S. Ogawa, E. A. Rachmilewitz, and R. Oltzik, "The effects of protein conformation on the heme symmetry in high spin ferric heme proteins as studied by electron paramagnetic resonance," Journal of Biological Chemistry, vol. 246, no. 10, pp. 3342-3355, 1971.

[42] A. Dhakshinamoorthy and K. Pitchumani, "Clay-anchored non-heme iron-salen complex catalyzed cleavage of $\mathrm{C}=\mathrm{C}$ bond in aqueous medium," Tetrahedron, vol. 62, no. 42, pp. 9911-9918, 2006.

[43] G. C. Silva, G. L. Parrilha, N. M. F. Carvalho et al., "A bio-inspired $\mathrm{Fe}$ (III) complex and its use in the cyclohexane oxidation," Catalysis Today, vol. 133-135, no. 1-4, pp. 684-688, 2008.

[44] F. Farzaneh, M. Poorkhosravani, and M. Ghandi, "Utilization of immobilized biomimetic iron complexes within nanoreactors of Al-MCM-41 as cyclohexane oxidation catalyst," Journal of Molecular Catalysis A, vol. 308, no. 1-2, pp. 108-113, 2009.

[45] S. Tanase and E. Bouwman, "Selective conversion of hydrocarbons with $\mathrm{H}_{2} \mathrm{O}_{2}$ using biomimetic non-heme iron and manganese oxidation catalysts," Advances in Inorganic Chemistry, vol. 58, pp. 29-75, 2006.

[46] G. Roelfes, M. Lubben, R. Hage, L. Que Jr., and B. L. Feringa, "Catalytic oxidation with a non-heme iron complex that generates a low-spin FeIIIOOH intermediate," Chemistry-A European Journal, vol. 6, no. 12, pp. 2152-2159, 2000.

[47] P. A. MacFaul, K. U. Ingold, D. D. M. Wayner, and L. Que Jr., "A putative monooxygenase mimic which functions via well-disguised free radical chemistry," Journal of the American Chemical Society, vol. 119, no. 44, pp. 10594-10598, 1997.

[48] F. Gozzo, "Radical and non-radical chemistry of the Fentonlike systems in the presence of organic substrates," Journal of Molecular Catalysis A, vol. 171, no. 1-2, pp. 1-22, 2001. 


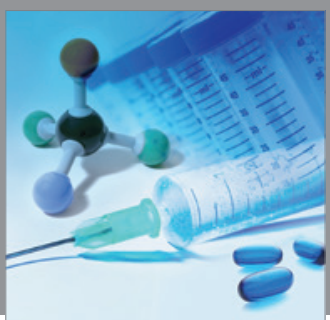

International Journal of

Medicinal Chemistry

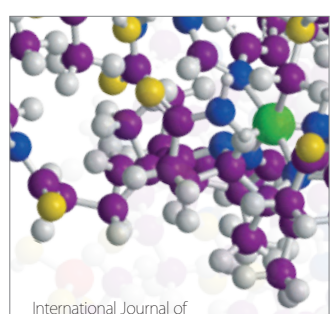

Carbohydrate Chemistry

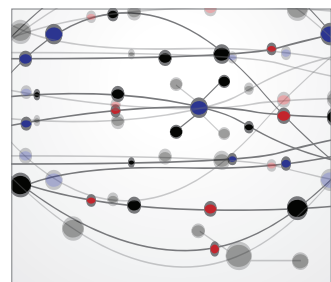

The Scientific World Journal
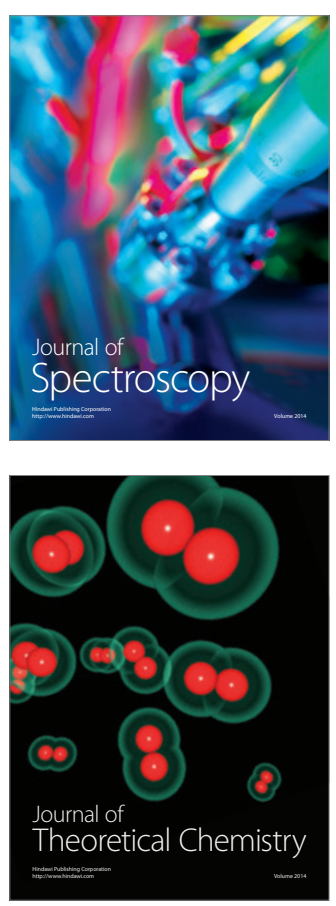
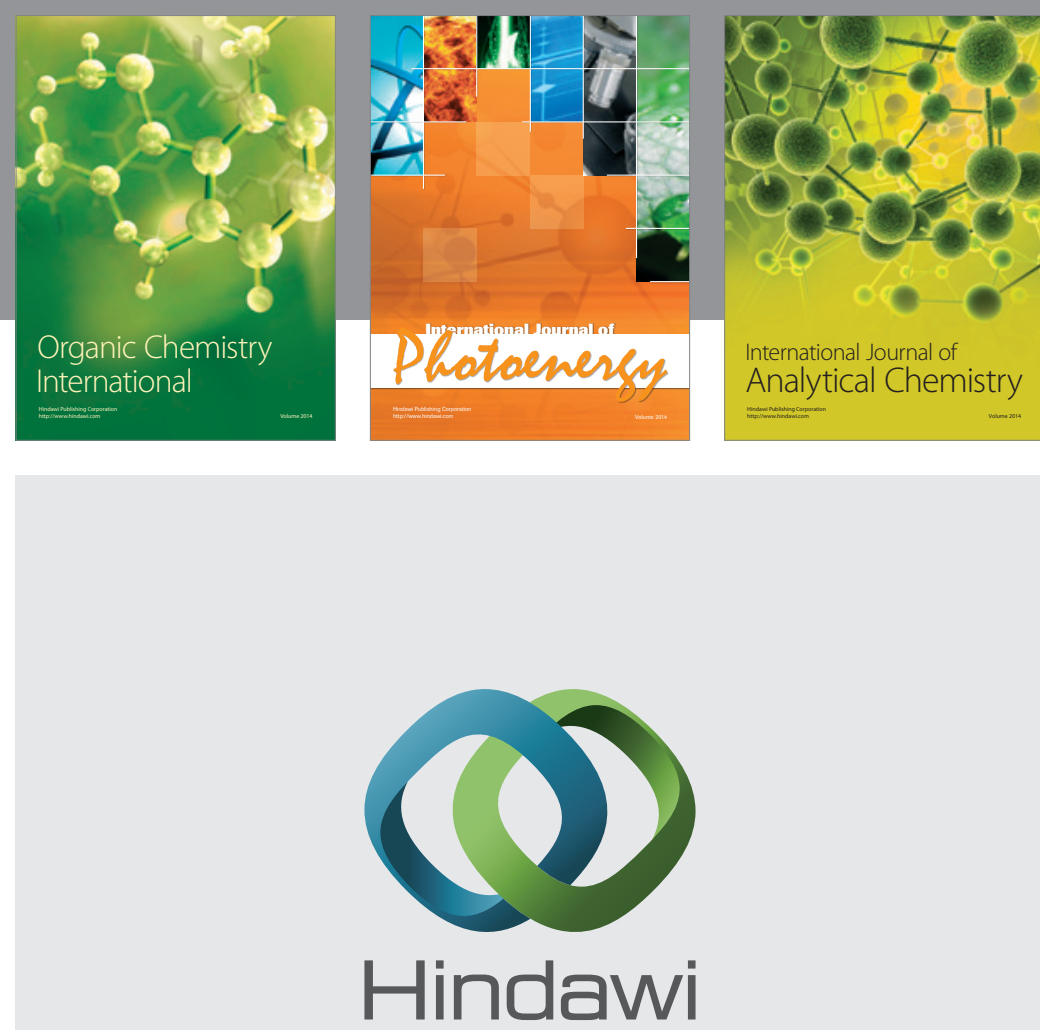

Submit your manuscripts at

http://www.hindawi.com
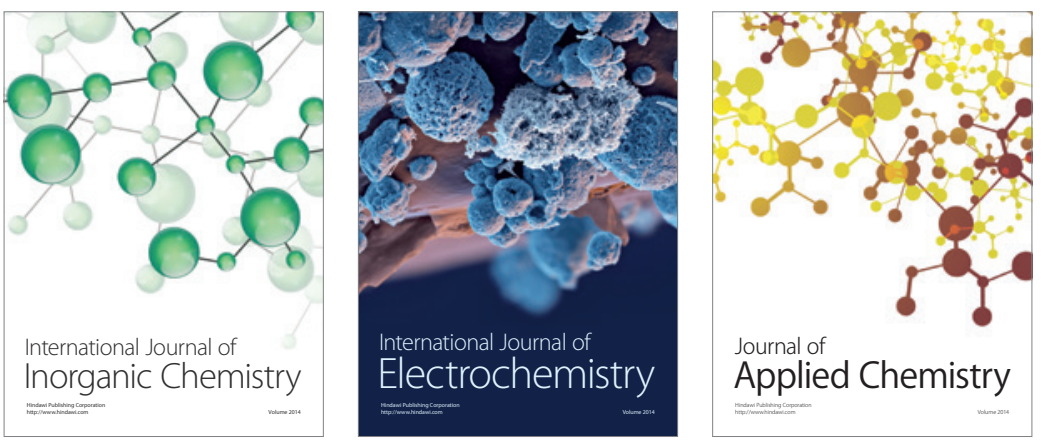

Journal of

Applied Chemistry
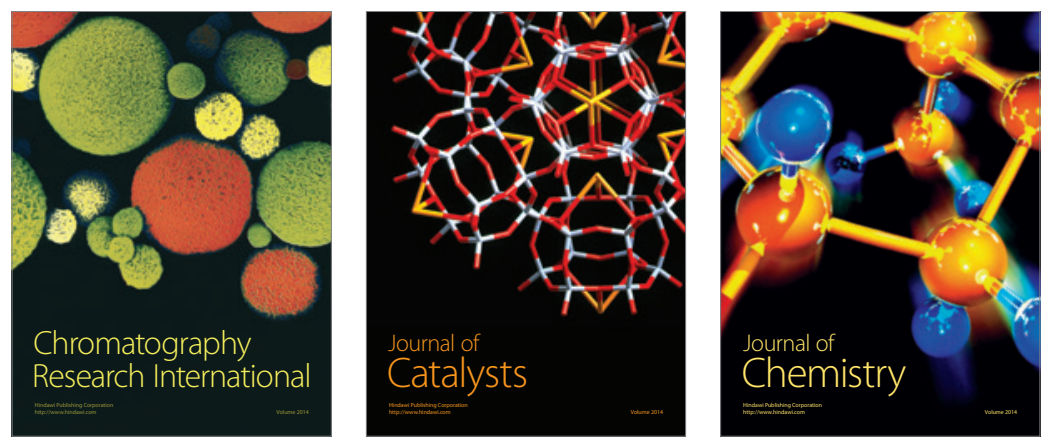
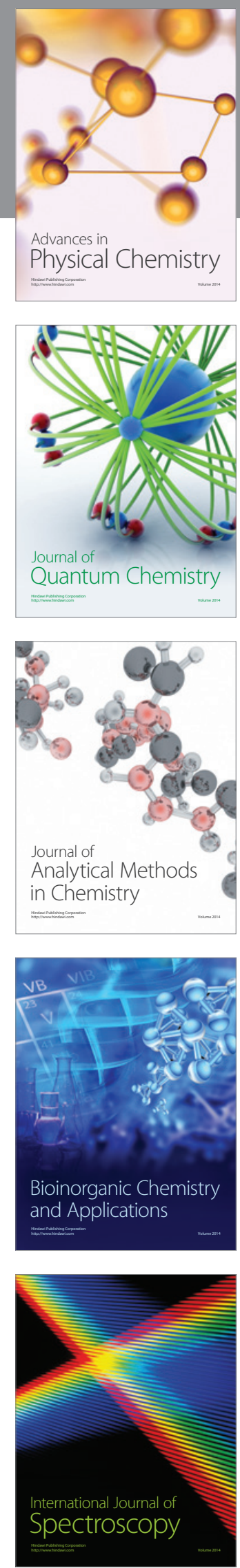